appear in the Bulletin of the Health Organisation. The Organisation has also been requested to determine which food elements are most acutely lacking in the present dietary of enemy-occupied countries, so that foods prepared by the Allied Food Relief Organization should, in the form of adequate complement rations, compensate present deficiencies. Information on the health situation in Europe was summarized in a series of notes on the prevalence, trend and probable course of typhus fever, cerebro-spinal meningitis, enteric fever, scarlet fever, smallpox, poliomyelitis, etc., and typhus fever was also the subject of a special study. The Singapore Bureau functioned until less than a week before the occupation of Singapore by the Japanese in January 1942. The activities of the Health Information Service have been maintained, and a study on the significance of names of communicable diseases in various languages was amplified and extended to form the basis of a comprehensive glossary in twenty-four languages of the communicable diseases. Research has continued on several subjects on the agenda of the Permanent Commission on Biological Standardization, including the nature of the toxins produced by the tetanus germ and by Bacillus perfringens, one of the agents of gas gangrene.

In regard to the Control of the Drug Traffic, international supervision has been impaired by the deterioration of communications, and difficulties in obtaining the necessary supplies have in some South American countries led to plans to produce raw opium and to manufacture drugs. The report directs attention to the danger that an excess of manufacture over legitimate needs may follow, and to the importance of taking, as soon as possible, all necessary steps to restore the full measures of control as they existed before the War. Work has already commenced on a post-war planning programme in this field, which includes a study and review of present national and international systems of control, with the view of suggesting improvements, and a study has been made of the legal position of drug addicts and current methods for treatment of addiction. The collections of the Library comprised about 318,200 volumes at the end of 1942, and in view of the exceptional facilities for work which the documentary material available will offer after the War, the secretariat is studying the means by which a gradual return to normal conditions may be effected.

\section{Smithsonian Institution : Annual Report}

THE report of the Secretary of the Smithsonian Institution for the year ending June 30, 1943, includes the report of the secretary and the financial report of the executive committee of the Board of Regents, together with the usual reports of the United States National Museum, the National Gallery of Art, the National Collection of Fine Art, the Freer Gallery of Art, the Bureau of American Ethnology, the International Fxchange Service, the Astrophysical Observatory and on the Library. The secretary's report points out that all personnel and facilities of the Institution and its branches were made available and extensively used in the prosecution of the War, although the normal activities were kept alive to the extent of continuing observations the cessation of which would leave permanent gaps in records essential for future investigations and of maintaining and caring for the national collections. All other research and exploratory projects not required for the orderly resumption of cultural activities after the War have been suspended, except those activities relating to closer cultural co-operation with the other American republics. Much of the Institution's contribution to the war effort is of an indirect nature. More than a thousand recorded inquiries had been answered up to the close of the fiscal year, and a list of selected examples tabulated by the War Com. mittee shows not only the wide range of these questions but also the extent to which modern total war depends on scientific knowledge.

War research projects have also been concerned with many different branches of science, including anthropology, biology, geology, physics and meteorology, and these projects occupied almost the whole time of the instrument and mechanical shops of the Astrophysical Observatory, the Division of Radiation and Organisms and the Division of Engineering, as well as of numerous individual members of the scientific staff. With regard to inter-American co-operation, the report refers to the organization of an Inter-American Society of Geography and Anthropology, with membership open to scientific workers anywhere in the hemisphere. More than 700 members have already been enrolled. The first part of a check list of the coleopterous insects of Mexico, Central America, the West Indies and South America is now in the Press as a bulletin of the National Museum. A prediction of the march of solar variation during 1939-45 based on periodicities revealed by the solar-constant values published in vol. 6 of the Annals of the Astrophysical Observatory shows that the years $1940-47$ will be the most important years to study the sun's variations since the early twenties, and for this reason every effort has been made to keep the three field observatories in Chile, California and New Mexico in operation. With regard to the international exchanges, the report records that the Office of Censorship lifted in January 1943 the ban imposed in April 1942 on sending abroad the Congressional Record and the Federal Register.

\section{Office Organization in Engineering Works}

A BOokLET issued by the British Standards Institution, "Office Organisation and Practice" (B.S.1100; Part 10; 1943), states in some detail the underlying principles of good office management and clerical organization, and gives practical guidance as to the installation of a system and the technique of office and clerical organization. It is addressed primarily to engineering firms of 250-1,000 employees with offices of 20-100 clerks, but the large amount of basic information on office practice condensed and set out simply in this booklet should be equally valuable to smaller firms in all branches of industry. Sections are included on the planning of systems; the design and use of forms ; the use and selection of machines and other devices, with an appendix listing suppliers; accommodation, lay-out, lighting and heating requirements of offices; personnel organization, including the grading of jobs and standards of performance and incentives ; training, selection, coordination and control of staff, and methods of inspection of work. Typing is dealt with in a separate section including both selection and training and the pool system, while a further section deals with communications, both inward and outward mail, the use of telephones and messengers. There is a short 
section on filing and another on sales invoicing. A short bibliography and an index add to the value of the publication.

\section{Institution of Electrical Engineers : Annual Report}

AccordING to the report for the year 1943-44 of the Council of the Institution of Electrical Engineers, total membership on March 31, 1944, numbered 24,558 , and of those there were 11,924 corporate members ; 2,944 elections to all classes of membership were made during the previous twelve months. During the year 562 meetings were held in London and at the local centres. The Wireless Section held fifteen meetings, the Measurements Section eight, the Transmission Section eight, the Installations Section seven, and there were six informal meetings. There are nine students sections. Post-war planning has received close attention at the hands of the committee appointed for the purpose, and reports have been published on "Education and Training for Engineers", the "Organization of Post-War Electrical Research", and on "Electricity Supply, Distribution and Installation." A report on "Electricity in Post-War Building" has been completed by the Electrical Installations Committee and is being published by H.M. Stationery Office. The Council's report also deals with various phases of the Institution's war effort, with technical investigations, joint activities with other institutions, and with the subject of education. The revised eleventh edition of the Regulations for the Electrical Equipment of Buildings has been issued during the year.

\section{Monthly Astronomical Newsletter}

BART J. BoK, Harvard Observatory, prepares a Newsletter each month for the American Astronomical Society which is intended to keep scientific societies informed about progress in various branches of astronomy during the disruption of exchange of information. Some of the notes are duplicated in other publications, such as Sky and Telescope, and by Science Service. The present issue, No. 17, contains brief references to papers and notices in Harvard Announcement Cards, the Astrophysical Journal, Popular Astronomy, etc. A considerable portion is devoted to a review of contributions by Dr. N. T. Bobrovnikoff and others on the physical properties of comets.

\section{The Night Sky in July}

Full moon occurs on July 6d. 04h. 27m. U.T., and new moon on July 20d. $05 \mathrm{~h}$. $42 \mathrm{~m}$. The following conjunctions with the moon take place: July 18d. 08 h., Saturn $1^{\circ} \mathrm{N}$.; July 22d. 0lh., Mercury $0.7^{\circ} \mathrm{S}$.; July 22d. 20h., Jupiter $2^{\circ}$ S. ; July 23d. 11h., Mars $2^{\circ} \mathrm{S}$. The following conjunctions in addition to the above also take place: July 5d. 08h., Mars in conjunction with Jupiter, Mars $0 \cdot 2^{\circ}$ N. ; July 10d. 04h., Mars in conjunction with Regulus, Mars $0.7^{\circ} \mathrm{N}$.; July 20 d. $12 \mathrm{~h}$., Jupiter in conjunction with Regulus, Jupiter $0.5^{\circ}$ N.; July 28d. 08h., Mercury in conjunction with Regulus, Mercury $0 \cdot 01^{\circ} \mathrm{N}$.; July $29 \mathrm{~d}$. 17h., Mercury in conjunction with Jupiter, Mercury $0 \cdot 7^{\circ} \mathrm{S}$. Occultations of stars brighter than magnitude 6 are as follows: July 2d. 21h. $20 \cdot 9 \mathrm{~m} ., \theta$ Libr $(D)$; July 30d. 21h. $57 \cdot 7 \mathrm{~m}$., $\chi$ Ophi. $(D)$. The times refer to the latitude of Greenwich and $(D)$ means disappearance. Mercury is in inferior conjunction on July 1. At the middle of the month the planet sets $50 \mathrm{~m}$. after the sun and at almost the same interval at the end of July. Venus is too close to the sun to be conveniently observed until late in the month. On July 31 the planet sets less than half an hour after the sun. Mars, in the constellation of Leo, can still be observed as it sets $2 \mathrm{~h}$. after the sun at the beginning of July and $1 \mathrm{~h}$. $10 \mathrm{~m}$. after sunset on July 31. Jupiter, in the constellation of Leo, is drawing near the sun, setting only $50 \mathrm{~m}$. after sunset at the end of July. Saturn is no longer visible. The earth reaches aphelion on July 3 when its distance from the sun is 94,560,000 miles. An annular eclipse of the sun, invisible at Greenwich, takes place on July 20. At Bombay the magnitude of the eclipse is $0 \cdot 95$, at Hong Kong $0 \cdot 90$, and at Madras $0 \cdot 80$.

\section{Announcements}

THE following elections to the Royal Society have been made: fellow of the Royal Society under Statute 12 : the Right Hon. S. M. Bruce, High Commissioner for Australia in London. Foreign members: Dr. O. T. Avery, bacteriologist, member of the. Rockefeller Institute, New York; Prof. M. Lugeon, professor of general geology and stratigraphy in the University of Lausanne ; Prof. The Svedberg, professor of physical chemistry in the University of Uppsala; Prof. N. E. Svedelius, professor of botany in the University of Uppsala ; Prof. S. Timoshenko, professor of engineering mechanics in the University of Michigan.

THe director of the Chinese National Central Library has offered to provide British scholars with Chinese material for specialist researches, and to arrange for its translation into English if this is desired. The Library will also forward lists of books available to interested institutions in Great Britain. The British Council has undertaken to act as intermediary on the British side; all inquiries should be addressed to the Director, Books Department, British Council, 3 Hanover Street, London, W.1.

Two prizes of 200 dollars each, offered by Mr. A. Cressy Morrison, to be known as the A. Cressy Morrison Prizes in Natural Science, will be awarded in December 1944 by the New York Academy of Sciences. Papers, which must embody the results of original research not previously published, must be submitted on or before October 1, 1944, to the Executive Secretary of the New York Academy of Sciences, at the American Museum of Natural History, Central Park West at 79th Street, New York, N.Y.

THE University of Birmingham is to award AngloAmerican studentships to encourage research in some branch of petroleum technology. These studentships will normally be awarded for one year, but may be renewed for a second year, the value of the award being $£ 225$ for the first year and $£ 250$ for the second year, if renewed. They are open to graduates of the University of Birmingham and science graduates of other universities. Applications, which should include a statement of age, academic qualifications and career, should be submitted to the Registrar of the University of Birmingham by July 15. Applicants must also submit the names of two referees.

ErRatum. In the communication "Thermal Fatigue in Metals" by W. Boas and R. W. K. Honeycombe printed in Nature of April 22, p. 494, the illustration has been inverted: photomicrograph $d$ should be $a ; c$ should be $b ; b$ should be $c$; and $a$ should be $d$. 